\title{
The Inhibitory Effects of Plant Derivate Polyphenols on the Main Protease of SARS Coronavirus 2 and Their Structure-Activity Relationship
}

\author{
Thi Thanh Hanh Nguyen ${ }^{1}$, Jong-Hyun Jung ${ }^{2}$, Min-Kyu Kim ${ }^{2}{ }^{\circledR}$, Sangyong Lim ${ }^{2}{ }^{\oplus}$, Jae-Myoung Choi ${ }^{3}$, \\ Byoungsang Chung ${ }^{3}$, Do-Won Kim ${ }^{4}$ and Doman Kim ${ }^{1,5, *(D)}$ \\ 1 Institutes of Green Bioscience and Technology, Seoul National University, \\ Pyeongchang-gun 25354, Gang-won-do, Korea; hara2910@snu.ac.kr \\ 2 Radiation Research Division, Korea Atomic Engery Research Institute, Jeongeup 56212, Jeollabuk-do, Korea; \\ Jungih83@kaeri.re.kr (J.-H.J.); mkkim@kaeri.re.kr (M.-K.K.); saylim@kaeri.re.kr (S.L.) \\ 3 Ottogi Sesame Mills Co., Ltd., Eumseong-gun 27623, Chungcheongbuk-do, Korea; \\ mjchoi@ottogism.co.kr (J.-M.C.); bschung@ottogism.co.kr (B.C.) \\ 4 Department of Physics, Gangneung-Wonju National University, Gangneung 25457, Gangwon-do, Korea; \\ Do.Won.Kim@cern.ch \\ 5 Graduate School of International Agricultural Technology, Seoul National University, \\ Pyeongchang-gun 25354, Gangwon-do, Korea \\ * Correspondence: kimdm@snu.ac.kr; Tel.: +82-33-339-5720; Fax: +82-33-339-5716
}

\section{check for} updates

Citation: Nguyen, T.T.H.; Jung, J.-H.; Kim, M.-K.; Lim, S.; Choi, J.-M.; Chung, B.; Kim, D.-W.; Kim, D. The Inhibitory Effects of Plant Derivate Polyphenols on the Main Protease of SARS Coronavirus 2 and Their Structure-Activity Relationship. Molecules 2021, 26, 1924. https:// doi.org/10.3390/molecules26071924

Academic Editors: Elisa Ovidi and Antonio Tiezzi

Received: 20 February 2021

Accepted: 25 March 2021

Published: 30 March 2021

Publisher's Note: MDPI stays neutral with regard to jurisdictional claims in published maps and institutional affiliations.

Copyright: (c) 2021 by the authors. Licensee MDPI, Basel, Switzerland. This article is an open access article distributed under the terms and conditions of the Creative Commons Attribution (CC BY) license (https:/ / creativecommons.org/licenses/by/ $4.0 /)$.

\begin{abstract}
The main protease $\left(\mathrm{M}^{\text {pro }}\right)$ is a major protease having an important role in viral replication of the severe acute respiratory syndrome coronavirus 2 (SARS-CoV-2), the novel coronavirus that caused the pandemic of 2020. Here, active M $\mathrm{M}^{\text {ro }}$ was obtained as a $34.5 \mathrm{kDa}$ protein by overexpression in E. coli BL21 (DE3). The optimal pH and temperature of $\mathrm{M}^{\text {pro }}$ were 7.5 and $37^{\circ} \mathrm{C}$, respectively. $\mathrm{M}^{\text {pro }}$ displayed a $K_{m}$ value of $16 \mu \mathrm{M}$ with Dabcyl-KTSAVLQ $\downarrow S G F R K M E-E d a n s$. Black garlic extract and 49 polyphenols were studied for their inhibitory effects on purified $\mathrm{M}^{\text {pro }}$. The $\mathrm{IC}_{50}$ values were $137 \mu \mathrm{g} / \mathrm{mL}$ for black garlic extract and 9-197 $\mu \mathrm{M}$ for 15 polyphenols. The mixtures of tannic acid with puerarin, daidzein, and/or myricetin enhanced the inhibitory effects on $\mathrm{M}^{\mathrm{pro}}$. The structure-activity relationship of these polyphenols revealed that the hydroxyl group in $\mathrm{C}^{\prime}, \mathrm{C}^{\prime}, \mathrm{C}^{\prime}$ in the B-ring, $\mathrm{C} 3$ in the $\mathrm{C}$-ring, $\mathrm{C} 7$ in A-ring, the double bond between $\mathrm{C} 2$ and $\mathrm{C} 3$ in the $\mathrm{C}$-ring, and glycosylation at $\mathrm{C} 8$ in the A-ring contributed to inhibitory effects of flavonoids on $\mathrm{M}^{\text {pro }}$.
\end{abstract}

Keywords: main protease; SARS-CoV-2; polyphenol; kinetic; structure-activity relationship; black garlic

\section{Introduction}

A new coronavirus disease, termed coronavirus disease 2019 (COVID-19), was first identified in Wuhan, China in December 2019 (Hasan et al., 2020). COVID-19 has spread to 235 countries resulting in 81,947,503 confirmed cases and 1,808,041 confirmed deaths by 2 January 2020 according to the World Health Organization (WHO) (covid19.who.int) (accessed on 2 January 2021) and the infection and mortality is increasing day by day. Due to rapid dissemination and deaths, COVID-19 was declared a pandemic for the first time by WHO on 11 March 2020 [1]. COVID-19 has become a global public health crisis, devastating the global economy, and affecting all stages of the education system [2]. Imposing social distancing and self-isolation, restricting travel, closing school, wearing masks, improving immunity, and using air-disinfectant and surface-sanitizing agents are current methods to limit COVID-19 infection [2,3] due to its human-to-human transfer via aerosol transmission [4].

COVID-19 is caused by a novel severe acute respiratory syndrome-related coronavirus (SARS-CoV-2) [5] which belongs to the $\beta$-coronavirus type and is closely related to MERS-CoV and SARS-CoV [6,7]. Like other members of coronaviruses, the genome of 
SARS-CoV-2 is a positive sense, single-stranded RNA $(\sim 30 \mathrm{~kb})$ enveloped and contains at least 6 open reading frames (ORFs) [7]. When the virus infects the cell, its genome acts as the mRNA and initiates the synthesis of polyproteins pp1a and pp1b which are essential for viral replication and transcription [8]. These polyproteins encode by two proteases called main protease (Mpro) or $3 C$-like protease and papain-like protease [8]. Thus, $\mathrm{M}^{\text {pro }}$ is considered one of the important targets for blocking viral replication. At present, there are no antiviral drugs on the market for COVID-19 treatment [9]. Broad-spectrum antibiotics such as amoxicillin, azithromycin, and fluoroquinolones, antiviral drugs such as ritonavir, remdesivir, oseltamivir, chloroquine, and lopinavir, corticosteroids such as methylprednisolone, and convalescent plasma are combined to use for COVID-19 treatment [10,11]. More than 200 clinical trials are ongoing (clinicaltrials.gov) (accessed on 11 October 2020).

Nutraceuticals are foods that provide medical or health benefits such as avoiding side effects, protecting human health against chronic diseases, improving human health, and are economically affordable [12-15]. In addition, herbal medicines have been used for COVID19 treatment in China [16]. Herbal medicines not only showed the prevention of COVID19 infection in healthy persons but also improved the health state of treated patients [16]. While screening nutrients and herbal medicines for COVID-19, we found that black garlic showed inhibitory effects on COVID-19 Mpro. Black garlic has a higher total phenolic and total flavonoid content than raw garlic [17]. Black garlic contains various phenolic acids including gallic acid, vanillic acid, chlorogenic acid, caffeic acid, ferulic acid, and coumaric acid), and flavonoids including catechin, epicatechin, epigallocatechin (EGCG), quercitrin, myricetin, resveratrol, morin, and quercetin [17]. Besides the antioxidant, cardioprotection, anti-cancer, anti-inflammatory, anti-aging, and protective activities, polyphenols have antiviral activities against enterovirus, influenza virus, SARS-CoV, Zika, and dengue virus [18-21]. In our previous study, polyphenols such as ampelopsin, puerarin, quercetin, daidzein, epigallocatechin gallate (EGCG), and gallocatechin gallate (GCG) were shown to inhibit the 3CL $\mathrm{CL}^{\text {ro }}$ of SARS-CoV [20]. M ${ }^{\text {pro }}$ sequence identity between SARS-CoV and SARS-CoV-2 was found to be $96 \%$ [22]. Also, the inhibitory effects of EGCG and theaflavin on Mpro of SARS-CoV-2 were confirmed [23]. Therefore, it is essential to study the inhibitory effects of each polyphenol on SARS-CoV-2 $\mathrm{M}^{\text {pro }}$ and their structure-activity relationship. In this study, the Mpro of SARS-CoV-2 was overexpressed in E. coli BL21(DE3) using IPTG as an inducer and purified using Ni-NTA chromatography. Its proteolytic activity was confirmed by using Dabcyl-KTSAVLQSGFRKME-Edans (FRET) as a substrate. The optimum $\mathrm{pH}$, $\mathrm{pH}$ stability, optimum temperature, and temperature stability of SARS-CoV-2's Mpro were studied. Also, the Michaelis-Menten constant $\left(K_{m}\right)$ and the effect of DMSO concentration on Mpro activity were studied. Then, the inhibitory effects of black garlic extract and 49 polyphenols on $\mathrm{M}^{\text {pro }}$ and their structure-activity relationships were investigated. The $50 \%$ inhibitory concentration $\left(\mathrm{IC}_{50}\right)$ of black garlic and 15 polyphenols were determined. In addition, the effects of mixtures of polyphenols (tannic acid, puerarin, daidzein, and myricetin) on $\mathrm{M}^{\text {pro }}$ activity were studied.

\section{Results}

\subsection{Biochemical Characterization of SARS-CoV-2 $M^{\text {pro }}$}

The nucleotide sequences encoding SARS-CoV-2 Mpro were optimized for expression in E. coli through a custom gene synthesis service of Genscript. It was expressed in E. coli BL21(DE3) by using $1.0 \mathrm{mM}$ IPTG at $16{ }^{\circ} \mathrm{C}$ for $12 \mathrm{~h}$, purified using Ni-Sepharose chromatography, and confirmed by SDS-PAGE (Figure 1A). A $34.5 \mathrm{kDa}$ protein was observed on $12 \%$ SDS-PAGE (Figure 1A). It had activity with Dabcyl-KTSAVLQ $\downarrow$ SGFRKME-Edans, a SARS-CoV 3CL ${ }^{\text {ro }}$ substrate (Nguyen et al., 2012) in $50 \mathrm{mM}$ Tris- $\mathrm{HCl} \mathrm{pH} \mathrm{7.5.} \mathrm{The} \mathrm{purified}$ $\mathrm{M}^{\text {pro }}$ reached maximum activity at $\mathrm{pH} 7.5$ (Figure 1B). Mpro showed over $90 \%$ activity at the $\mathrm{pH}$ from 5.6 to 9.9 after $24 \mathrm{~h}$ incubation at $4{ }^{\circ} \mathrm{C}$. Maximum activity of $\mathrm{M}^{\text {pro }}$ was obtained at $37{ }^{\circ} \mathrm{C}$ (Figure $1 \mathrm{C}$ ). A thermos-stability assay showed that Mpro was stable at $37{ }^{\circ} \mathrm{C}$ (Figure 1C), then it was left at $76 \%$ activity when kept at $45^{\circ} \mathrm{C}$ for $24 \mathrm{~h}$. Mpro activity was not detected when kept at $60^{\circ} \mathrm{C}$ for $24 \mathrm{~h}$ (Figure 1C). The $K_{m}$ value of $\mathrm{M}^{\text {pro }}$ calculated from 
the Lineweaver-Burk double reciprocal plot was $16 \mu \mathrm{M}$ with Dabcyl-KTSAVLQSGFRKMEEdans (Figure 1D and Figure S1).

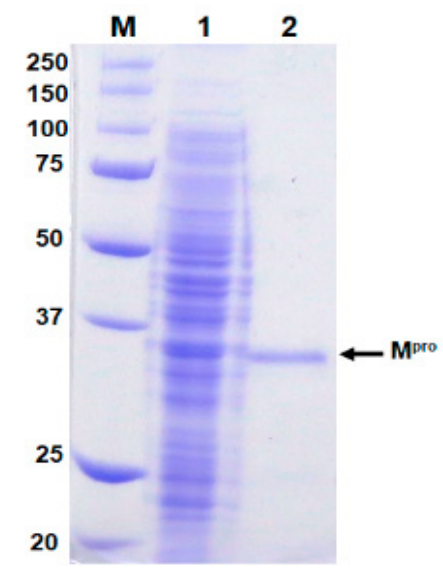

(A)

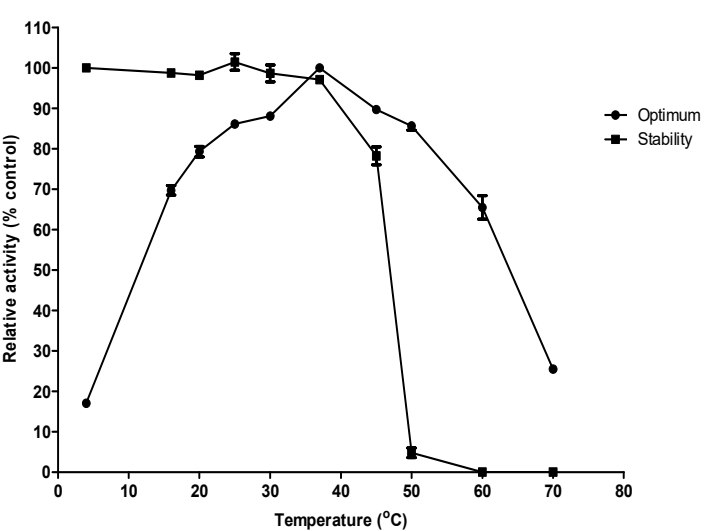

(C)

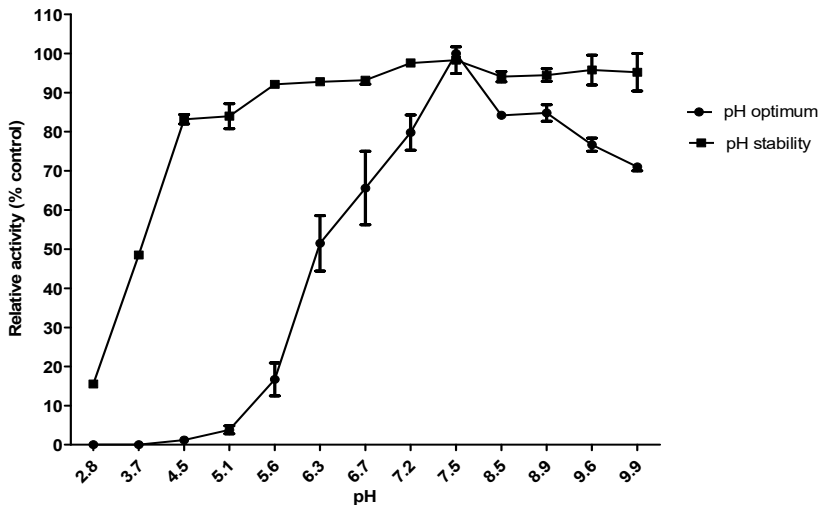

(B)

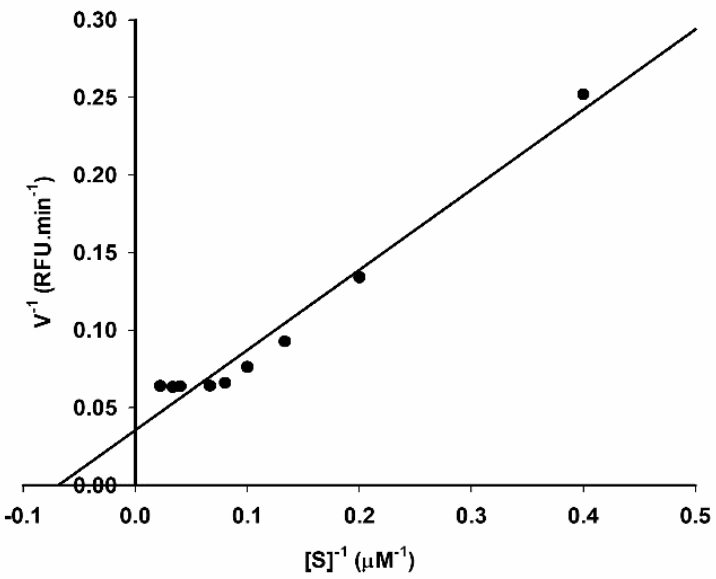

(D)

Figure 1. SDS-PAGE analysis (A), optimum $\mathrm{pH}$ and $\mathrm{pH}$ stability (B), optimum temperature and temperature stability (C), and Lineweaver-Burk plot for determination of $K_{m}$ value of purified SARS-CoV-2 Mpro (D). (A) Lane M: the molecular mass markers, lane 1: cell lysate with $1 \mathrm{mM}$ IPTG induction to overexpress Mpro, lane 2: purified Mpro after using the Ni-NTA column chromatography. (B) Buffers used: glycine- $\mathrm{HCl}$ ( $\mathrm{pH}$ 3.0), sodium acetate buffer ( $\mathrm{pH}$ 5.0-6.5), Tris buffer ( $\mathrm{pH}$ 7.0-9.0), and glycine-NaOH buffer ( $\mathrm{pH}$ 9.5-11.0). For $\mathrm{pH}$ stability, the enzyme was kept at $4{ }^{\circ} \mathrm{C}$ for $24 \mathrm{~h}$ under various $\mathrm{pH}$ conditions ( $\mathrm{pH} 3.0-11.0$ ). (C) For thermal stability, the enzyme was kept from 4 to $60^{\circ} \mathrm{C}$ for $24 \mathrm{~h}$. The enzyme activity was measured with $20 \mu \mathrm{M}$ of FRET as a substrate at $37^{\circ} \mathrm{C}$ for $30 \mathrm{~min}$. (D) The kinetic parameter of $\mathrm{M}^{\text {pro }}$ was added to different concentrations of FREP substrate $(2.5-45 \mu \mathrm{M})$ to the reaction mixture composed of $\mathrm{M}^{\text {pro }}$ in $50 \mathrm{mM}$ Tris- $\mathrm{HCl} \mathrm{pH} 7.5$. The reactions were run at $37^{\circ} \mathrm{C}$ for $8 \mathrm{~min}$.

\subsection{Influence of Dimethylsulfoxide on $M^{\text {pro }}$ Activity}

Dimethylsulfoxide (DMSO) is a potent organic solvent that dissolves a variety of organic compounds due to its high dielectric constant and stereochemistry [24]. Although DMSO has been used as an additive, drug carrier to cells, and a cryoprotector, it can affect enzyme activity $[24,25]$. Therefore, the effect of DMSO on M ${ }^{\text {pro }}$ activity was studied (Figure 2). $\mathrm{M}^{\text {pro }}$ was stable in the presence of up to $10 \%(v / v)$ DMSO (Figure 2). Then, its activity was reduced when the DMSO concentration increased over 10\% (v/v). At 50\% (v/v) DMSO, M ${ }^{\text {pro }}$ activity was not detected (Figure 2). 


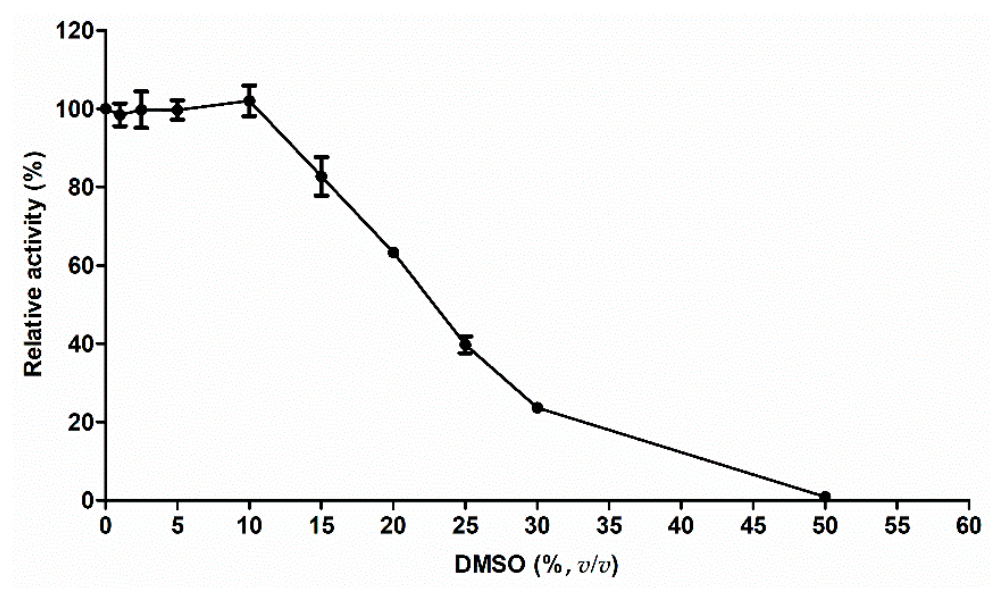

Figure 2. Effect of DMSO on SARS-CoV-2 Mpro activity. Mpro was incubated for $30 \mathrm{~min}$ at $37^{\circ} \mathrm{C}$ in $50 \mathrm{mM}$ Tris-HCl buffer $\mathrm{pH} 7.5$ containing $20 \mu \mathrm{M}$ of FRET with different concentrations of DMSO $(0-50 \%, v / v)$.

\subsection{Inhibitory Effects of Plant Derivative Polyphenols on SARS-CoV-2 $M^{\text {pro }}$}

Polyphenols are bioactive compounds found in fruits, vegetables, grains, and herbs and have been widely studied owing to their nutraceutical activity, such as anti-bacterial activities, anti-viral activities, anti-cancer, anti-inflammatory, and anti-diabetes [26]. Polyphenols have been divided into many classes depending on their strength ring. Lignans, phenolic alcohols, stiblins, phenolic acids, and flavonoids are the main polyphenol classes [27]. In this study, we found that black garlic extract inhibited $100 \%$ SARS-CoV2 $\mathrm{M}^{\text {pro }}$ activity at $0.5 \mathrm{mg} / \mathrm{mL}$. The $\mathrm{IC}_{50}$ value of extracted garlic acid was $137 \pm 10 \mu \mathrm{g} / \mathrm{mL}$ (Table 1). Black garlic is produced by heating raw garlic at high temperatures. Black garlic contains different phenolic acids such as gallic acid, caffeic acid, vanillic acid, ferulic acid, and chlorogenic acid, and various flavonoids such as epicatechin, catechin, epigallocatechin gallate, resveratrol, myricetin, and quercetin [17]. Thus, we examined the inhibitory effects of 49 polyphenols from different classes on $\mathrm{M}^{\text {pro. }}$. The chemical structures of 49 polyphenols and their inhibitory activity on $\mathrm{M}^{\text {pro }}$ are shown in Figure 3 and Table 1 . Among them, caffeine, capsaicin, teniposide, and idebenone did not inhibit $\mathrm{M}^{\text {pro }}$ at $200 \mu \mathrm{M}$. M $\mathrm{M}^{\text {pro }}$ inhibitory effects of kaempferol, quercetin- $4^{\prime}-O-\alpha$-D-glucopyranoside, naringin, epicatechin, catechin, chrysin, trigonelline, ascorbic acid, hydroquinone, gallic acid, pyrogallol, and catechol were less than $20 \%$ compared to the control while the other compounds including astragalin, myricein, quercetin, quercetagenin, ampelopsin, ampelopsin- $4^{\prime}-O-\alpha$-D-glucopyranoside, naringenin, epigallocatechin gallate (EGCG), vitexin, daidzein, puerarin, resveratrol, tannic acid, chlorogenic acid, and caffeic acid showed over $50 \%$ inhibitory activity on $\mathrm{M}^{\text {pro }}$. The compounds exhibiting more than $50 \%$ inhibitory activity on $\mathrm{M}^{\text {pro }}$ were selected to determine $\mathrm{IC}_{50}$. Their $\mathrm{IC}_{50}$ values were from 9 to $197 \mu \mathrm{M}$ (Table 1 ). 

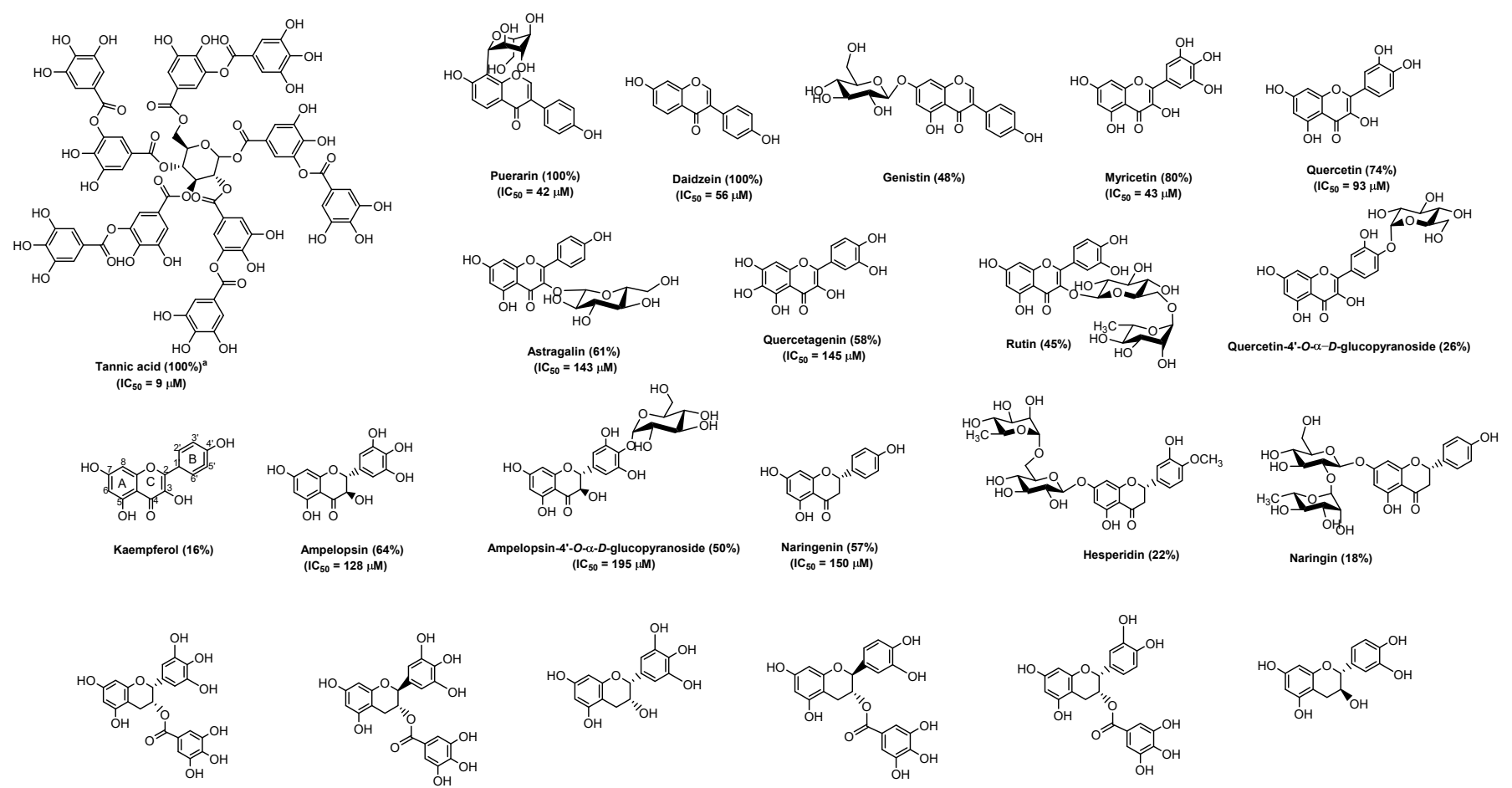

Epigallocatechin gallate (EGCG) (53\%)
\[ \left(\mathrm{IC}_{50}=171 \mu \mathrm{MM}\right) \]

Gallocatechin gallate (GCG) $(50 \%)$

Epigallocatechin (EGC) (23\%)
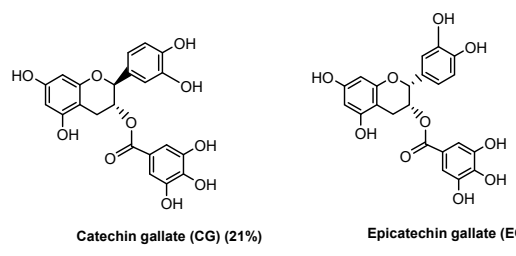

$$
{ }_{\mathrm{OH}}^{\text {HO }}
$$
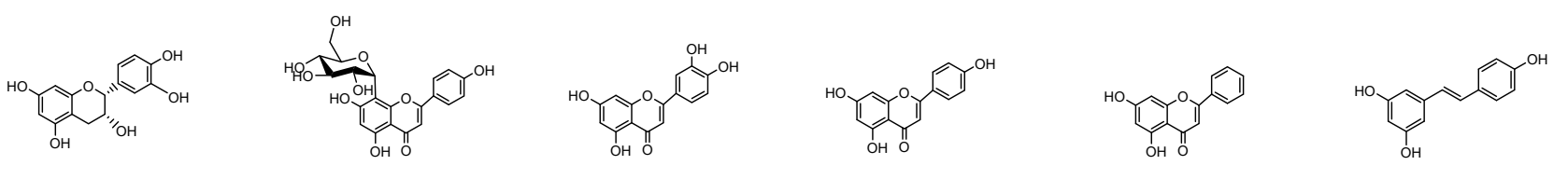

Epicatechin (EC) $(8 \%)$

$$
\begin{aligned}
& \text { Vitexin (52\%) } \\
& \text { (IC } 50 \text { 180 } \mu \text { M) }
\end{aligned}
$$

Luteolin (45\%)

Apigenin (25\%)

$$
\text { Chrysin (9\%) }
$$

Resveratrol (68\%)
$\left(\mathrm{IC}_{50}=103 \mu \mathrm{M}\right)$

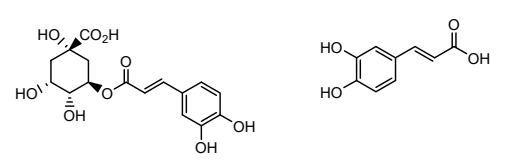

$$
\begin{array}{cc}
\text { Chlorogenic acid (61\%) } & \text { Caffeic acid (50\%) } \\
\left({ }^{\left(C_{50}\right.}=140 \mu \mathrm{M}\right) & \left(\mathrm{CC}_{50}=197 \mu \mathrm{M}\right)
\end{array}
$$

(n)

Mangiferin-(1 $\rightarrow 6)-\alpha-D$-glucopyranoside $(40 \%)$
筷

Demethoxycurcumin (48\%)

Curcumin (41\%)

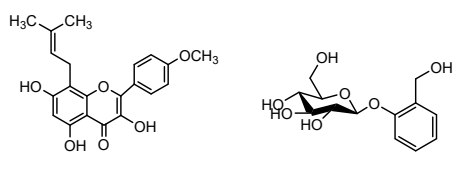

Icaritin (31\%)

Salicin $(20 \%)$

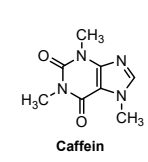

idibenone

HO

Capsaicin


Bisdemethoxycurcumin (34\%)

Ferrulic acid (46\%)

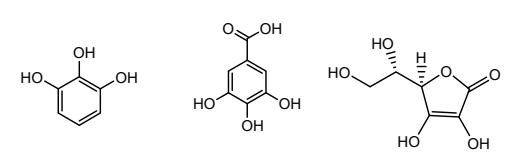

Pyrogallol (14\%) Gallic acid $(7 \%)$

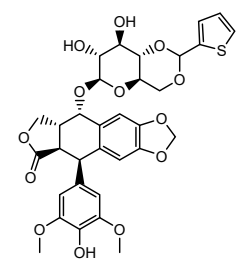

Teniposide

Figure 3. Chemical structure of plant derivate polyphenols against SARS-CoV-2 Mpro. 
Table 1. The inhibitory effect of polyphenol compounds on SARS-CoV-2 Mpro.

\begin{tabular}{|c|c|c|c|c|c|}
\hline No & Compound & Group & Source & Inhibition (\%) & $\mathrm{IC}_{50}(\mu \mathrm{M})$ \\
\hline 1 & Black garlic extract & Mixtures & SerimFood & 100 & $137 \pm 10 \mu \mathrm{g} / \mathrm{mL}$ \\
\hline 2 & Tannic acid & Tannoid & Sigma & 100 & 9 \\
\hline 3 & Puerarin & Isoflavone & Sigma & 100 & $42 \pm 2$ \\
\hline 4 & Daidzein & Isoflavone & Sigma & 100 & 56 \\
\hline 5 & Genistin & Isoflavone & Sigma & 48 & ND \\
\hline 6 & Myricetin & Flavonol & Sigma & 80 & $43 \pm 1$ \\
\hline 7 & Quercetin & Flavonol & Sigma & 74 & $93 \pm 5$ \\
\hline 8 & Astragalin & Flavonol & Amore Pacific & 61 & $143 \pm 9$ \\
\hline 9 & Quercetagenin & Flavonol & Sigma & 58 & $145 \pm 6$ \\
\hline 10 & Rutin & Flavonol & Sigma & 45 & ND \\
\hline 11 & $\begin{array}{l}\text { Quercetin- } 4^{\prime}-O-\alpha-\mathrm{D}- \\
\text { glucopyranoside }\end{array}$ & Flavonol & Synthesized & 26 & ND \\
\hline 12 & Kaempferol & Flavonol & Sigma & 16 & ND \\
\hline 13 & Ampelopsin & Flavanonol & Sigma & 64 & $128 \pm 5$ \\
\hline 14 & $\begin{array}{l}\text { Ampelopsin- } 4^{\prime}-O-\alpha-\mathrm{D}- \\
\text { glucopyranoside }\end{array}$ & Flavanonol & Synthesized & 50 & $195 \pm 5$ \\
\hline 15 & Naringenin & Flavanone & Sigma & 57 & $150 \pm 10$ \\
\hline 16 & Hesperidin & Flavanone & Sigma & 22 & ND \\
\hline 17 & Naringin & Flavanone & Sigma & 18 & ND \\
\hline 18 & Epigallocatechin gallate (EGCG) & Flavan-3-ols & Sigma & 53 & $171 \pm 5$ \\
\hline 19 & Gallocatechin gallate & Flavan-3-ols & Sigma & 50 & ND \\
\hline 20 & Epigallocatechin (EGC) & Flavan-3-ols & Sigma & 23 & ND \\
\hline 21 & Catechin gallate (CG) & Flavan-3-ols & Sigma & 21 & ND \\
\hline 22 & Epicatechin gallate (ECG) & Flavan-3-ols & Sigma & 21 & ND \\
\hline 23 & Catechin & Flavan-3-ols & Sigma & 9 & ND \\
\hline 24 & Epicatechin (EC) & Flavan-3-ols & Sigma & 8 & ND \\
\hline 25 & Vitexin & Flavone & Sigma & 52 & $180 \pm 6$ \\
\hline 26 & Luteolin & Flavone & Sigma & 45 & ND \\
\hline 27 & Apigenin & Flavone & Sigma & 25 & ND \\
\hline 28 & Chrysin & Flavone & Sigma & 9 & ND \\
\hline 29 & Resveratrol & Stilbenoid & Sigma & 68 & $103 \pm 6$ \\
\hline 30 & Chlorogenic acid & Hydrocinnamic acid & Sigma & 61 & 140 \\
\hline 31 & Caffeic acid & Dihydroxycinnamic acid & Sigma & 50 & $197 \pm 1$ \\
\hline 32 & Demethoxycurcumin (DMC) & Diarylheptanoid & TCI chemical & 48 & ND \\
\hline 33 & Bisdemethoxycurcumin (BDMC) & Diarylheptanoid & TCI chemical & 34 & ND \\
\hline 34 & Curcumin & Diarylheptanoid & TCI chemical & 41 & ND \\
\hline 35 & Ferulic acid & Hydrocinnamic acid & Sigma & 46 & ND \\
\hline 36 & $\begin{array}{c}\text { Mangiferin-(1-> } \\
\text { 6)- } \alpha \text {-D-glucopyranoside }\end{array}$ & Xanthonoid & Synthesized & 40 & ND \\
\hline 37 & Mangiferin & Xanthonoid & Sigma & 35 & ND \\
\hline 38 & Icaritin & Favonol & Sigma & 31 & ND \\
\hline 39 & Salicin & Salicylate & Sigma & 20 & ND \\
\hline 40 & Pyrogallol & Benzenetriol & Sigma & 14 & ND \\
\hline 41 & Gallic acid & & Sigma & 7 & ND \\
\hline 42 & Ascorbic acid & & Sigma & 4 & ND \\
\hline 43 & Catechol & Bezenediol & Sigma & 3 & ND \\
\hline 44 & Hydroquinone & & Sigma & 3 & ND \\
\hline 45 & Trigonelline & Alkaloid & Sigma & 1 & ND \\
\hline 46 & Caffein & Alkaloid & Sigma & 0 & ND \\
\hline 47 & Idebenone & 1,4-benzoquinone & TCI chemical & 0 & ND \\
\hline 48 & Salicylic acid & $\begin{array}{c}\text { Monohydroxybenzoic } \\
\text { acid }\end{array}$ & Sigma & 0 & ND \\
\hline 49 & Capsaicin & Capsaicinoid & Sigma & 0 & ND \\
\hline 50 & Teniposide & Podophyllotoxin & Sigma & 0 & ND \\
\hline
\end{tabular}




\subsection{Structure-Activity Relationship of Plant Derivative Polyphenols against SARS-CoV-2 Mro}

First, the inhibitory activity of compounds in the sample group was compared. In the flavonol group, the order of Mpro inhibition activity was as follows: kaempferol < quercetin- $4^{\prime}-O$ - $\alpha$-D-glucopyranoside < rutin < quercetagenin < astragalin < quercetin < myricetin at $200 \mu \mathrm{M}$. Flavonols are a class of flavonoids that has a 3-hydroflavone backbone.

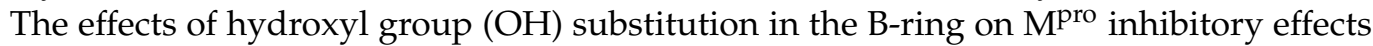
were evaluated. The inhibitory effects of quercetin, which has $3^{\prime}-\mathrm{OH}$ and $4^{\prime}-\mathrm{OH}$ at the B-ring, and kaempferol, which has $4^{\prime}-\mathrm{OH}$ group at the B-ring, were lower than that of myricetin which has $3^{\prime}-\mathrm{OH}, 4^{\prime}-\mathrm{OH}$, and $5^{\prime}-\mathrm{OH}$ groups at the B-ring. The absence of $3^{\prime}-$ $\mathrm{OH}$ and $4^{\prime}-\mathrm{OH}$ groups at the B-ring was the reason for the lower inhibitory activity of kaempferol and quercetin than myricetin. When quercetin was glycosylated at $\mathrm{C}^{\prime}{ }^{\prime}$ in the B-ring (quercetin-4'-O- $\alpha$-glucopyranoside) and C3 in the C-ring (rutin), its inhibitory effect was decreased. The presence of the $\mathrm{OH}$ group at $\mathrm{C} 6$ in the A-ring of quercetagenin decreased the inhibitory activity compared to quercetin. Therefore, the $\mathrm{OH}$ at $\mathrm{C} 6$ in the A-ring, the $\mathrm{C}^{\prime}, \mathrm{C4}^{\prime}, \mathrm{C} 5^{\prime}$ in the B-ring, and the $\mathrm{C} 3$ in C-ring affected Mpro inhibitory activity. Ampelopsin is dihyromyricetin. The existence of double bonds between C2 and C3 in the C-ring of myricetin was the reason for the higher inhibitory activity of myricetin than ampelopsin.

In the flavanone group, the order of $\mathrm{M}^{\text {pro }}$ inhibitory activity was as follows: naringin $<$ hesperidin < naringenin. Naringenin is glycosylated naringin. However, its inhibitory activity was 3.2-fold higher than that of naringin. Hesperidin that contained glycosylation at 7-OH at the A-ring like the naringenin and the methoxy group at position $5^{\prime}$ of the B-ring was shown to have higher inhibitory activity than that of naringin but lower inhibitory activity than that of naringenin, indicating that glycosylation at the $C 7$ position enhanced

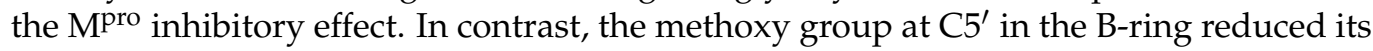
inhibitory activity.

In the flavan-3-ols group, the order of the inhibitory effect was as follows: epicatechin (EC) < catchin < epicatechin gallate $(\mathrm{ECG})<$ catechin gallate $(\mathrm{CG})<$ epigallocatechin $(\mathrm{EGC})$ $<$ gallocatechin gallate (GCG) < epigallocatechin gallate (EGCG) (Table 1). EGCG, GCG, and ECG which contained three $\mathrm{OH}$ groups at $\mathrm{C}^{\prime}{ }^{\prime}, \mathrm{C}^{\prime}$, and $\mathrm{C}^{\prime}$ in the B-ring showed higher $M^{\text {pro }}$ inhibitory activity than that of the remaining compounds (EC, catechin, $C G$, and EGC), suggesting that the $\mathrm{OH}$ group at $\mathrm{C}^{\prime}, \mathrm{C}^{\prime}, \mathrm{C}^{\prime}$ in the B-ring increased the inhibitory activity against $M^{\text {pro }}$, similar to the compounds in the flavonol group. EGCG, GCG, CG, and ECG, which have a galloyl moiety at C3 in the C-ring, showed higher M ${ }^{\text {pro }}$ inhibitory activity, suggesting that galloyl moiety at C3 of the C-ring increased the inhibitory activity on $\mathrm{M}^{\text {pro }}$. Thus, the inhibitory activity of gallic acid on $\mathrm{M}^{\text {pro }}$ was studied. Gallic acid inhibited 6.9\% Mpro activity at $200 \mu \mathrm{M}$. Besides gallic acid, we also tested the inhibitory effects of tannic acid composed of 10 galloyl moieties. Tannic acid inhibited 100\% Mpro activity and its $\mathrm{IC}_{50}$ value was $9 \mu \mathrm{M}$. Compared to myricetin, EGCG, which has the same three $\mathrm{OH}$ groups in the B-ring, galloy moiety at $\mathrm{C} 3$ in the $\mathrm{C}$-ring, no double bonds between $\mathrm{C} 2$ and $\mathrm{C} 3$, and no $\mathrm{C} 4=\mathrm{O}$ in the $\mathrm{C}$-ring, displayed decreased inhibitory activity on $\mathrm{M}^{\text {pro }}$.

In the flavone group, the order of inhibitor activity on Mpro was as follows: chrysin < apigenin < luteolin < vitexin. Chrysin, lacking the $\mathrm{OH}$ group in the B-ring, exhibited the lowest inhibitory activity on $\mathrm{M}^{\text {pro }}$. Compared to the three compounds (luteolin, chrysin, and apigenin), we found that the more the $\mathrm{OH}$ group increased in the B-ring, the more the inhibitory effects on $\mathrm{M}^{\text {pro }}$ increased. While with attacked glucosyl moiety at $\mathrm{C} 8$ in the A-ring, the inhibitory activity on Mpro increased by 2-fold that of apigenin. The difference between flavone and isoflavone is the linked position of B-ring to C-ring. Compared to apigenin, which contained the same $\mathrm{OH}$ group in the B-ring but the B-ring was linked in position $\mathrm{C} 3$ in the $\mathrm{C}$-ring and lacked the $\mathrm{OH}$ group at $\mathrm{C} 5$ in the A-ring, daidzein showed an increased inhibition effect on $\mathrm{M}^{\text {pro }}$. Puerarin, which contained the 8-C-glucoside of daidzein, exhibited a slightly higher inhibitory effect on $\mathrm{M}^{\text {pro }}$ than that of daidzein. From the inhibitory effect of compounds from flavone and isoflavone, we concluded that the glycosylation at the $\mathrm{C} 8$ position increased the inhibitory effect on $\mathrm{M}^{\text {pro }}$. 
In the diarylheptanoid group, the order of inhibitory effects was as follows: bisdemethoxycurcumin < curcumin < dimethylcurcumin. In this group, curcumin contained two methoxy groups (C2' and $\mathrm{C}^{\prime \prime}$ ) and showed higher inhibitory activity on $\mathrm{M}^{\text {pro }}$ than bisdemethoxycurcumin which lacked the methoxy group. However, its inhibitory activity was lower than that of dimethylcurcumin, which contained one methoxy group in $\mathrm{C}^{\prime}$.

\subsection{Combinative Inhibitory Effects on SARS-CoV-2 Mro of Polyphenols}

Herbal medicines have been used to treat COVID-19 in China [16]. According to the National Administration of Traditional Chinese Medicine, herbal medicines not only showed the ability to prevent COVID-19 infection in healthy persons but also improved the state of health in treated patients [16]. Most of the clinical studies used herbal extract mixtures [11]. Tannic acid found in red wines, herbaceous, legumes, sorghum, bananas, raspberries, and persimmons, belongs to the tannin family. The concentrations of tannins in red wines were estimated at 5 100 mM. Tannic acid inhibited not only Mpro SARSCoV2 but also transmembrane protease serin 2 (TMPRSS2) [28]. Although tannic acid inhibits two different SARS-CoV2 enzymes, it has been reported to form complexes with protein, starch, and digestive enzymes causing the nutritional value to decrease [29-31]. Therefore, reducing the amount of tannic acid may reduce its side effects. In this study, we tested the effect of different combinations of tannic acid with myricetin, puerarin, and/or daidzein on $\mathrm{M}^{\text {pro }}$ activity. The concentration of tannic acid was fixed at $5 \mu \mathrm{M}$, while the concentrations of myricetin, puerarin, and daidzein were fixed at $20 \mu \mathrm{M}$. The inhibitory effects of mixing tannic acid with myricetin, puerarin, and/or daidzein on $\mathrm{M}^{\text {pro }}$ are shown in Figure 4. The inhibitory effects of a single polyphenol on $\mathrm{M}^{\text {pro }}$ were $30 \pm 1 \%$ at $5 \mu \mathrm{M}$ tannic acid, $23 \pm 5 \%$ at $20 \mu \mathrm{M}$ puerarin, $27 \pm 3 \%$ at $20 \mu \mathrm{M}$ daidzein, and $34 \pm 1 \%$ at $20 \mu \mathrm{M}$ myricetin. The inhibitory effects increased to $41 \pm 2 \%$ at $5 \mu \mathrm{M}$ tannic acid with $20 \mu \mathrm{M}$ puerarin, $50 \%$ at $5 \mu \mathrm{M}$ tannic acid with $20 \mu \mathrm{M}$ daidzein, and $58 \pm 2 \%$ at $5 \mu \mathrm{M}$ tannic acid with $20 \mu \mathrm{M}$ myricetin. The Mpro inhibitory activities of flavonoids at $45 \mu \mathrm{M}$ were $50.8 \pm 2 \%$ for puerarin, $43 \%$ for daidzein, and $50.5 \pm 4 \%$ for myricetin, while they were $62 \pm 6 \%$ at $5 \mu \mathrm{M}$ tannic acid with $20 \mu \mathrm{M}$ puerarin and $20 \mu \mathrm{M}$ daidzein, $69 \pm 2 \%$ at $5 \mu \mathrm{M}$ tannic acid with $20 \mu \mathrm{M}$ puerarin and $20 \mu \mathrm{M}$ myricetin, and $69 \pm 2 \%$ at $5 \mu \mathrm{M}$ tannic acid with $20 \mu \mathrm{M}$ puerarin and $20 \mu \mathrm{M}$ myricetin. The highest inhibitory activity on Mpro (77 $\pm 1 \%$ ) was achieved at $5 \mu \mathrm{M}$ tannic acid with $20 \mu \mathrm{M}$ puerarin, $20 \mu \mathrm{M}$ daidzein, and $20 \mu \mathrm{M}$ myricetin.

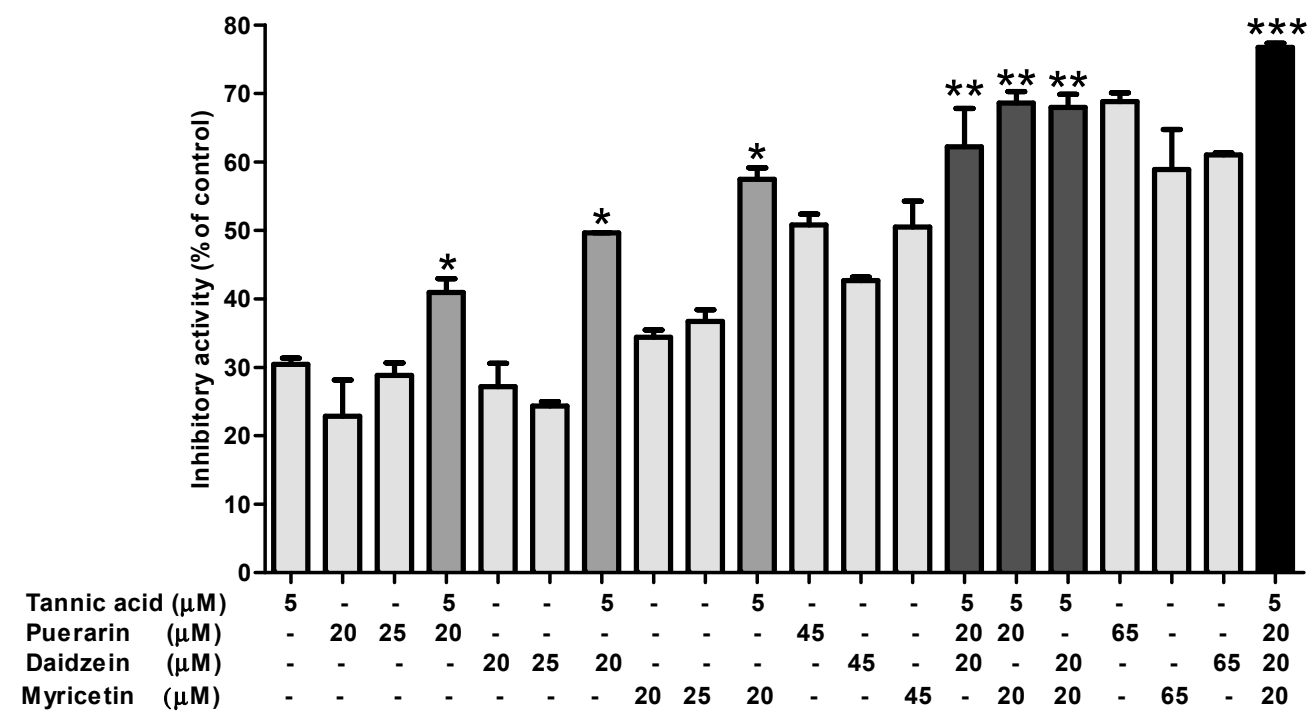

Figure 4. Inhibitory effects on SARS-CoV-2 Mpro of mixtures of tannic acid with puerarin, daidzein, and/or myricetin. All tests were performed in triplicate, and bars indicate the mean and standard deviation. ${ }^{*}, * *, * * *: p<0.05$ compared to $25 \mu \mathrm{M}$, $45 \mu \mathrm{M}, 65 \mu \mathrm{M}$ of each puerarin, daidzein, and myricetin, respectively. 


\section{Discussion}

The SARS-CoV-2 $\mathrm{M}^{\text {pro }}$ is one of the best-characterized targets for antiviral drug discovery. It plays an essential role in virus replication by digesting the viral polyproteins at more than 11 sites on the large polyprotein $1 \mathrm{ab}$. The recognition sequence at most sites is $\mathrm{LQ} \downarrow(\mathrm{S}, \mathrm{A}, \mathrm{G})$ (the cleavage site is indicated by $\downarrow$ ) [32] similar to that in SARS-CoV $3 C L^{\text {pro }}[33,34]$. Since inhibiting $M^{\text {pro }}$ activity will block viral replication, we selected SARS-CoV2 $\mathrm{M}^{\text {pro }}$ as the target protein and Dabcyl-KTSAVLQ $\downarrow S G F R K M E-E d a n s$ as its commercially available substrate. The biochemical characterization of $\mathrm{M}^{\text {pro }}$ showed that the optimum temperature, $\mathrm{pH}$, and $K_{m}$ value were $37^{\circ} \mathrm{C}, \mathrm{pH} 7.5$, and $16 \mu \mathrm{M}$, respectively. The $K_{m}$ value of the purified Mpro was similar to that of the SARS-CoV $3 \mathrm{CL}^{\text {pro }}$ expressed in Pichia pastoris with $15 \pm 1 \mu \mathrm{M}$ [20] and to that of the SARS-CoV 3CL pro expressed in E. coli with $17 \pm 4 \mu \mathrm{M}$ [35]. We tested the influence of increasing concentrations of DMSO up to $50 \%(v / v)$. At up to $10 \%(v / v)$, we found no significant effects on SARS-CoV2 Mpro activity, but over 10\% (v/v), DMSO significantly inhibited $\mathrm{M}^{\text {pro }}$ activity. At $50 \%(v / v)$ DMSO, M Mro $^{\text {pro }}$ lost its activity. No significant effect of $10 \%(v / v)$ DMSO on SARS-CoV2 Mpro activity was observed, similar to that on SARS-CoV 3CL pro activity [34].

Polyphenols are a large family of phytochemicals with great chemical diversity as well as potential therapeutic diversity. Many polyphenols act as multi-target agents of high biochemical specificity and chemical diversity with lower cost, more covering mechanism, and minimal side effects. As one of the plant derivate polyphenols, curcumin down-regulated the coactivator of $\mathrm{HBV}$ transcription, peroxisome proliferator-activated receptor-gamma coactivator 1- $\alpha$ (PGC-1 $\alpha)$, and inhibited HBV gene replication and expression [36]. In another example, tannic acid inhibits two SARS-CoV2 enzymes [28]. Thi et al. reported that epigallocatechin gallate or gallocatechin gallate containing galloyl moiety at 3-OH of the C-ring was required for inhibitory activity on SARS-CoV 3CL pro [20]. Thus, polyphenols may be novel antiviral candidate compounds and lead-structures. In addition, polyphenols are inexpensive with minimal side effects. Polyphenols are known to be bioactive compounds of foods, species, medicinal plants, and nutraceuticals. Polyphenol intake varies within 50-1000 mg/day among different countries such as France (283-1000 mg/day), Spain (500-1100 mg/day), Italy (700 mg/day), Finland (890 mg/day), Brazil (534 mg/day), Japan (1500 mg/day), US (240-350 mg/day), China (50-500 mg/day), and Korea (320 mg/day) [37-39]. Thus, polyphenols have potential use in the prevention of SARS-CoV2. Numerous studies on herbal medicines against SARS-CoV-2 have been conducted in vitro, in vivo, and in ovo $[16,40,41]$. However, most clinical studies were performed with food or herb combinations based on the traditional Chinese formulas. Lianhuaqingwen is a Chinese patent medicine composed of 13 herbs [40,42]. It inhibited SARS-CoV-2 replication in a dose-dependent manner with an $\mathrm{IC}_{50}$ of $411 \mu \mathrm{g} / \mathrm{mL}$, reduced the production of pro-inflammatory cytokines, and affected particle morphology of the virus [40]; 61 polyphenols were identified in this herbal mixture. Therefore, we aimed to study the effects of bioactive compounds in herbal extracts on SARS-CoV-2 $\mathrm{M}^{\text {pro }}$ as well as their structure-activity relationship. Garlic is a popular medicinal food owing to its numerous health benefits (anticancer, antibacterial, antiviral, antidiabetic, antihypertensive, antioxidative, and immunity-enhancing benefits) [43]. However, raw garlic causes gastrointestinal discomfort and has a pungent taste and smell, resulting in a decline in its consumption. Black garlic, with a sweet and sour taste [43], overcame this drawback of raw garlic. Black garlic has more reducing sugar (80-fold), lipids (3.2-fold), organic acids (3.9-fold), total phenolic acids ( $\sim 7.8$-fold), flavonoids ( $\sim 3.5$-fold), polyphenols (1.8-fold), alkaloids (28.6-fold), and vitamins (1.3-fold) than raw garlic [17,44]. Also, chlorogenic acid, vanillic acid, and quercetin were newly synthesized, whereas the amount of other compounds, such as gallic acid, caffeic acid, coumaric acid, ferulic acid, catechin, epicatechin, epigallocatechin gallate, myricetin, resveratrol, and morin increased from 1.1- to 26.2-fold, which contributed to the enhancing of total phenolic acid and total flavonoid content by up to 7.8- and 3.5-fold, respectively [17]. From these results, we found that the inhibitory effect of black garlic on $\mathrm{M}^{\text {pro }}$ was possibly owing to its phenolic acids (gallic, chlorogenic, caf- 
feic, and ferulic) and flavonoid compounds (myricetin, quercetin, epigallocatechin gallate, epicatechin, catechin, and resveratrol) [17].

The COVID-19 pandemic started in December 2019 and has extended until now; there are no approved therapeutics for this disease. Although numerous researchers performed computational chemistry [45] and virtual screening of FDA-approved drugs [46] and flavonoid compounds [47-50] with $\mathrm{M}^{\text {pro }}$, their efficiencies against $\mathrm{M}^{\text {pro }}$ need to be confirmed by in vitro and in vivo experiments. To the best of our knowledge, among our tested polyphenols, EGCG and tannic acid have been reported to have inhibitory effects on $\mathrm{M}^{\text {pro }}$ with $\mathrm{IC}_{50}$ values of $7.6 \mu \mathrm{g} / \mathrm{mL}$ and $2.1 \mu \mathrm{M}$, respectively [23,45]. Here, we found that the EGCG and tannic acid inhibited $\mathrm{M}^{\text {pro }}$ with $\mathrm{IC}_{50}$ values of $171 \mu \mathrm{M}$ and $9 \mu \mathrm{M}$, respectively (Table 1). The differences in the results may be due to different substrate and reaction conditions used in each study. For example, Jang et al., (2020) performed the EGCG inhibition assay at $37^{\circ} \mathrm{C}$ for $5 \mathrm{~h}$ using the same substrate; however, Coelho et al., (2020) conducted the inhibition assay using MCA-AVLQSGFR-K(Dnp)-K$\mathrm{NH}_{2}$. Although we did not perform experiments to study the binding mode of these compounds by molecular docking, there are several reports that predict the inhibition mode of these compounds [48-50]. Molecular docking studies with $\mathrm{M}^{\text {pro }}$ protein showed that some compounds, such as rutin $(-9.2 \mathrm{kcal} / \mathrm{mol})$, hesperidin $(-8.1 \mathrm{kcal} / \mathrm{mol})$, naringin $(-8.1 \mathrm{kcal} / \mathrm{mol})$, EGCG $(-7.9 \mathrm{kcal} / \mathrm{mol})$, catechin $(-5.8 \mathrm{kcal} / \mathrm{mol})$, myricetin $(-5.9 \mathrm{kcal} / \mathrm{mol})$, and caffeic acid $(-5.1 \mathrm{kcal} / \mathrm{mol})$, had the highest binding energy and hydrogen-bonding interactions with key amino acid residues of $\mathrm{M}^{\text {pro }}[31,48,50]$. Our experiments confirmed that these compounds inhibited $\mathrm{M}^{\text {pro }}$ (Table 1). Although the polyphenols assessed in this study showed moderate inhibition against $\mathrm{M}^{\text {pro }}$, they may prevent or at least impede SARS-CoV-2 infection. COVID-19 therapies can be divided into two types depending on their targets [51], one is designed to boost the human immune system or inhibit the inflammatory process, and the other to directly attack the virus by hindering its replication and entry into the human cell. Polyphenols have been reported to affect the level and composition of immunoglobulins, inflammation, and immune cell populations [52]. For example, polyphenols such as curcumin, epigallocatechin gallate, naringenin, kaempferol, apigenin, and resveratrol decrease pro-inflammatory cytokines, according to in vitro and in vivo studies [46]. Thus, polyphenols not only inhibit SARS-CoV2 Mpro activity but also affect the human immune system. In addition, polyphenols are the most common and the largest plant compounds in the human diet. They are extracted from plants and found in foods and beverages. The dietary intake of polyphenols has been estimated to vary from 100 to $1000 \mathrm{mg} /$ day. Further studies of foods containing these polyphenols against SARS-CoV-2 are needed.

\section{Materials and Methods}

\subsection{Preparation of Active SARS-CoV-2 $\mathrm{M}^{\text {pro }}$}

SARS-CoV-2 Mpro gene was codon optimized and synthesized for expression in Escherichia coli based on Mpro amino acid sequence (GenBank accession MT483553.1: 32643569 aa) by Genscript (Piscataway, NJ, USA). M ${ }^{\text {pro }}$ was inserted into the pET28a vector (pET28a-Mpro) (Novagen, Darmstadt, Germany) for overexpression of $\mathrm{M}^{\text {pro }}$ protein with polyhistidine tags. pET28a-Mpro was transformed into E. coli BL21(DE3) using the heat shock method and then spread on LB agar containing $(50 \mu \mathrm{g} / \mathrm{mL})$ (Sigma). The plate was inoculated at $37^{\circ} \mathrm{C}$ overnight. LB supplemented with kanamycin was used for a single colony grown at $37^{\circ} \mathrm{C}$. One $\mathrm{mM}$ isopropyl $\beta$-D-1-thiogalactopyranoside (IPTG) (Sigma) was used to induce $\mathrm{M}^{\text {pro }}$ when the optical density $\left(\mathrm{OD}_{600}\right)$ became 0.5 . Induced cells were cultured at $16{ }^{\circ} \mathrm{C}$ with shaking (200 rpm) for $12 \mathrm{~h}$. Cells were harvested by centrifugation $\left(8000 \times \mathrm{g}\right.$ for $30 \mathrm{~min}$ at $\left.4{ }^{\circ} \mathrm{C}\right)$, resuspended in $50 \mathrm{mM}$ Tris- $\mathrm{HCl} \mathrm{pH} \mathrm{7.0,} \mathrm{and} \mathrm{lysed} \mathrm{by}$ sonication (Ultrasonic processor 250, Sonics and Materials Inc., Newtown, CT, USA). After sonication, cell lysate was obtained by centrifugation $(12,000 \times \mathrm{g}$ for $30 \mathrm{~min})$ and then loaded onto $12 \mathrm{~mL}$ of Ni-Agarose resin (Qiagen, Hilden, Germany). A buffer containing $50 \mathrm{mM}$ Tris- $\mathrm{HCl}, 100 \mathrm{mM} \mathrm{NaCl}, 300 \mathrm{mM}$ imidazole, $\mathrm{pH} 8.0$ was used to elute proteins from 
the Ni-Agarose column. Fractions containing purified proteins were obtained and dialyzed against a $50 \mathrm{mM}$ Tris- $\mathrm{HCl}$ buffer ( $\mathrm{pH} 7.5)$. Protein concentration was determined using a protein determination kit (Bio-Rad protein assay kit, Bio-Rad Laboratories, Hercules, CA, USA), and 12\% SDS-PAGE was used to confirm the purity of the protein.

Proteolytic activity of Mpro was measured by using fluorogenic peptide (DabcylKTSAVLQ $\downarrow S G F R K M E-E d a n s)$ (FRET) as a substrate (Nguyen et al., 2012). The reaction mixtures composed of $20 \mu \mathrm{M}$ of FRET substrate and $8 \mu \mathrm{g}$ of $\mathrm{M}^{\text {pro }}$ in $50 \mathrm{mM}$ Tris- $\mathrm{HCl}$ (pH 7.5) were run at $37^{\circ} \mathrm{C}$ for $30 \mathrm{~min}$. Relative fluorescence units (RFUs) were verified with SpectraMax M3 (Molecular Devices, San Jose, CA, USA) at excitation and fluorescence emission wavelengths of 355 and $538 \mathrm{~nm}$, respectively.

\subsection{Biochemical Characteristics of the Active SARS-CoV-2 $M^{\text {pro }}$}

\subsubsection{Effect of $\mathrm{pH}$ on Activity and Stability of SARS-CoV-2 Mpro}

The effect of $\mathrm{pH}$ on $\mathrm{M}^{\text {pro }}$ activity was studied at different $\mathrm{pHs}$ ranging from $\mathrm{pH}$ 3.0 to 11.0 using the following buffers: glycine- $\mathrm{HCl}(50 \mathrm{mM}, \mathrm{pH} 3.0)$, sodium acetate buffer (50 mM, pH 5.0-6.5), Tris- $\mathrm{HCl}$ buffer (50 mM, pH 7.0-9.0), and glycine-NaOH buffer (50 mM, pH 9.5-11.0) [53]. The optimum $\mathrm{pH}$ was determined by incubation of $\mathrm{M}^{\text {pro }}$ in each buffer for $30 \mathrm{~min}$ using $20 \mu \mathrm{M}$ of FRET as a substrate at $37^{\circ} \mathrm{C}$ for $30 \mathrm{~min}$. RFUs were recorded as described above.

The $\mathrm{pH}$ stability of $\mathrm{M}^{\text {pro }}$ was carried out by incubation of $\mathrm{M}^{\text {pro }}$ for $24 \mathrm{~h}$ in the chosen buffers at $4{ }^{\circ} \mathrm{C}$. Then, the $\mathrm{pH}$ of $\mathrm{M}^{\text {pro }}$ was accustomed to 7.5 by membrane dialysis. $\mathrm{M}^{\text {pro }}$ activity was carried out with $20 \mu \mathrm{M}$ of FRET at $37^{\circ} \mathrm{C}$ for $30 \mathrm{~min}$. RFUs were recorded as described above.

\subsubsection{Effect of Temperature on Activity and Stability of SARS-CoV-2 Mpro}

The effect of temperature on $\mathrm{M}^{\text {pro }}$ activity was performed by reacting a reaction mixture composed of Mpro enzyme and $20 \mu \mathrm{M}$ of FRET in $50 \mathrm{mM}$ Tris- $\mathrm{HCl}$ (pH 7.5) at various temperatures from 4 to $70^{\circ} \mathrm{C}$. RFUs were recorded as described above.

$M^{\text {pro }}$ temperature stability was performed by keeping the enzyme from 4 to $60{ }^{\circ} \mathrm{C}$ for $24 \mathrm{~h}$. Then, the enzyme was added to the reaction digest containing $20 \mu \mathrm{M}$ of FRET in $50 \mathrm{mM}$ Tris- $\mathrm{HCl}$ ( $\mathrm{pH} 7.5)$. The reactions were done at $37^{\circ} \mathrm{C}$ for $30 \mathrm{~min}$. RFUs were verified with SpectraMax M3 as described above.

\subsubsection{Effect of DMSO on SARS-CoV-2 Mpro Activity}

The effect of dimethyl sulfoxide (DMOS) on $\mathrm{M}^{\text {pro }}$ activity was measured by adding different concentrations of DMSO from 0 to $50 \%(v / v)$ to the reaction mixture comprising $\mathrm{M}^{\text {pro }}$ in $50 \mathrm{mM}$ Tris- $\mathrm{HCl} \mathrm{pH}$ 7.5. The FRET substrate was added to initiate the reaction. The control was a reaction without adding DMSO. The reactions were conducted at $37^{\circ} \mathrm{C}$ for $30 \mathrm{~min}$. RFUs were monitored as described above.

\subsubsection{Kinetic Characterization}

The kinetic parameter of Mpro was added to different concentrations of FREP substrate $(2.5-45 \mu \mathrm{M})$ to the reaction mixture composed of $\mathrm{M}^{\text {pro }}$ in $50 \mathrm{mM}$ Tris- $\mathrm{HCl} \mathrm{pH}$ 7.5. The reactions were run at $37^{\circ} \mathrm{C}$ for $8 \mathrm{~min}$. Reaction results were linear within this time. The Michaelis-Menten constant $\left(K_{m}\right)$ was obtained from the Lineweaver-Burk plot using the Sigmaplot program (Systat Software, San Jose, CA, USA).

\subsection{Inhibition Assay}

Black garlic extract and 49 compounds that were selected for Mpro inhibitory activity are listed in Table 1. A $16 \mu \mathrm{M}$ FRET substrate was added to the reaction digest containing $\mathrm{M}^{\text {pro }}$ and a $200 \mu \mathrm{M}$ inhibitor or $0.5 \mathrm{mg} / \mathrm{mL}$ of black garlic extract in $50 \mathrm{mM}$ Tris- $\mathrm{HCl}$ 
( $\mathrm{pH}$ 7.5) to start a reaction. The reaction was run at $37^{\circ} \mathrm{C}$ for $15 \mathrm{~min}$ and RFUs were recorded as above. The inhibition activity of $\mathrm{M}^{\mathrm{pro}}$ was calculated as follows:

$$
\text { Inhibition activity }(\%)=100-\left[\left(S-S_{0}\right) /\left(C-C_{o}\right)\right] \times 100
$$

where $C_{o}$ and $C$ were the RFUs of the control (buffer, enzyme, and substrate) after 0 and 15 min of reaction and $S_{o}$ and $S$ were the RFUs of the assay sample (buffer, inhibitor, enzyme, and substrate) after 0 and 15 min of reaction. Fifteen compounds and black garlic extract were selected for the $50 \%$ inhibitory concentration $\left(\mathrm{IC}_{50}\right)$ determination. $\mathrm{IC}_{50}$ was the $\mathrm{M}^{\text {pro }}$ inhibitor concentration necessary to reduce $50 \% \mathrm{M}^{\text {pro }}$ activity compared to the reaction without adding an inhibitor. To determine IC50, $16 \mu \mathrm{L}$ FRET substrate was added to the reaction digest containing $\mathrm{M}^{\text {pro }}$ and different concentrations of inhibitors $(1-400 \mu \mathrm{M})$ in $50 \mathrm{mM}$ Tris- $\mathrm{HCl}$ ( $\mathrm{pH} 7.5$ ) to start the reaction as described above.

\subsection{Combinative Inhibitory Effects of Selected Compounds}

The combinative inhibitory effects of tannic acid, puerarin, daidzein, and myricetin were performed by adding $5 \mu \mathrm{M}$ of tannic acid with $20 \mu \mathrm{M}$ of puerarin, and/or daidzein, and/or myricetin to a reaction mixture containing a $16 \mu \mathrm{M}$ FRET substrate and $\mathrm{M}^{\mathrm{pro}}$ in $50 \mathrm{mM}$ Tris- $\mathrm{HCl}$ ( $\mathrm{pH} 7.5)$ as described above.

\subsection{Statistical Analysis}

All experiments were performed in triplicate, and results were expressed as the mean \pm standard deviation. Statistical comparisons were made by one-way analysis of variance followed by Tukey's comparison tests on GraphPad Prism 8 (San Diego, CA, USA). Values were considered to be significant when $p<0.05$.

\section{Conclusions}

Here, we reported the overexpression and biochemical characterization of an active SARS-CoV-2 $\mathrm{M}^{\text {pro }}$. The purified $\mathrm{M}^{\text {pro }}$ was used to study the inhibitory effect of black garlic extract and 49 polyphenols. Black garlic extract and 15 polyphenols showed the inhibition of $\mathrm{M}^{\text {pro }}$ activity with $\mathrm{IC}_{50}$ values of $137 \mu \mathrm{g} / \mathrm{mL}$ and from 9 to $197 \mu \mathrm{M}$, respectively. From the structure-activity relationship of these polyphenols, we found that the hydroxyl group in $\mathrm{C}^{\prime}, \mathrm{C}^{\prime}, \mathrm{C}^{\prime}$ in the B-ring, $\mathrm{C} 3$ in the C-ring, $\mathrm{C} 7$ in the A-ring, the double bond between $\mathrm{C} 2$ and $\mathrm{C} 3$ in the $\mathrm{C}$-ring, and glycosylation at $\mathrm{C} 8$ in the A-ring contributed to the inhibitory activity of flavonoids on $\mathrm{M}^{\text {pro }}$. Different combinations of tannic acid with puerarin, daidzein, and/or myricetin also increased inhibitory effects on $\mathrm{M}^{\mathrm{pro}}$. Polyphenols are products extracted from plants and found in foods and beverages such as fruits, vegetables, tea, wine. Therefore, further studies of foods containing these polyphenols are needed.

Supplementary Materials: The following are available online, Figure S1: Michaelis-Menten plot for determination of $K_{m}$ value of purified SARS-CoV2 Mpro.

Author Contributions: Conceptualization, T.T.H.N., S.L. and D.K.; Methodology, T.T.H.N.; Validation, T.T.H.N., M.-K.K., S.L., J.-M.C., B.C., D.-W.K. and D.K.; Formal analysis, T.T.H.N., J.-H.J., M.-K.K., J.-M.C., B.C., D.-W.K. and D.K.; Data curation, T.T.H.N.; Writing-original draft preparation, T.T.H.N.; Writing-review and editing, T.T.H.N. and D.K. Supervision, D.K.; Project administration, D.K.; Funding acquisition, D.K. All authors have read and agreed to the published version of the manuscript.

Funding: This research was supported by a grant from the National Research Foundation of Korea (NRF), funded by the Ministry of Science and ICT (2018R1D1A1B07049569, T.T.H.N., 2018R1D1A1A09083366, D.W.K.). This research was partially supported by the Nuclear R\&D program of the Ministry of Science and ICT (MSIT), Republic of Korea, and by the Ottogi Corporation through the Research Project.

Institutional Review Board Statement: Not applicable.

Informed Consent Statement: Not applicable. 
Data Availability Statement: All data are within this manuscript.

Conflicts of Interest: The authors declare no conflict of interest.

Sample Availability: Samples of the compounds, black garlic extract, tannic acid, puerarin, daidzein, genistin, myricetin, quercetin, astragalin, quercetagenin, rutin, quercetin- 4 ' $-O-\alpha$-D-glucopyranoside, kaempferol, ampelopsin, ampelopsin-4'-O- $\alpha$-D-glucopyranoside, naringenin, hesperidin, naringin, epigallocatechin gallate, gallocatechin gallate, epigallocatechin, catechin gallate, epicatechin gallate, catechin, epicatechin, vitexin, luteolin, apigenin, chrysin, resveratrol, chlorogenic acid, caffeic acid, demethoxycurcumin, bisdemethoxycurcumin, curcumin, ferulic acid, mangiferin-(1->6)- $\alpha$-Dglucopyranoside, mangiferin, icaritin, salicin, pyrogallol, gallic acid, ascorbic acid, catechol, hydroquinone, trogonelline, caffeine, idebenone, salicylic acid, capsaicin, and teniposide are available from the authors.

\section{References}

1. Cucinotta, D.; Vanelli, M. WHO Declares COVID-19 a Pandemic. Acta Biomed. 2020, 91, 157-160. [PubMed]

2. Nicola, M.; Alsafi, Z.; Sohrabi, C.; Kerwan, A.; Al-Jabir, A.; Iosifidis, C.; Agha, M.; Agha, R. The socio-economic implications of the coronavirus pandemic (COVID-19): A review. Int. J. Surg. 2020, 78, 185-193. [CrossRef]

3. Lenzen, M.; Li, M.; Malik, A.; Pomponi, F.; Sun, Y.Y.; Wiedmann, T.; Faturay, F.; Fry, J.; Gallego, B.; Geschke, A.; et al. Global socio-economic losses and environmental gains from the Coronavirus pandemic. PLoS ONE 2020, 15, e0235654. [CrossRef]

4. Panyod, S.; Ho, C.T.; Sheen, L.Y. Dietary therapy and herbal medicine for COVID-19 prevention: A review and perspective. J. Tradit. Complement. Med. 2020, 10, 420-427. [CrossRef] [PubMed]

5. Dai, W.; Zhang, B.; Jiang, X.M.; Su, H.; Li, J.; Zhao, Y.; Xie, X.; Jin, Z.; Peng, J.; Liu, F.; et al. Structure-based design of antiviral drug candidates targeting the SARS-CoV-2 main protease. Science 2020, 368, 1331-1335. [CrossRef] [PubMed]

6. Kanhed, A.M.; Patel, D.V.; Teli, D.M.; Patel, N.R.; Chhabria, M.T.; Yadav, M.R. Identification of potential Mpro inhibitors for the treatment of COVID-19 by using systematic virtual screening approach. Mol. Divers. 2020, 25, 383-401. [CrossRef]

7. Chen, Y.; Liu, Q.; Guo, D. Emerging coronaviruses: Genome structure, replication, and pathogenesis. J. Med. Virol. 2020, 92, 418-423. [CrossRef]

8. Boopathi, S.; Poma, A.B.; Kolandaivel, P. Novel 2019 coronavirus structure, mechanism of action, antiviral drug promises and rule out against its treatment. J. Biomol. Struct. Dyn. 2020, 1-10. [CrossRef]

9. Joshi, T.; Joshi, T.; Sharma, P.; Mathpal, S.; Pundir, H.; Bhatt, V.; Chandra, S. In silico screening of natural compounds against COVID-19 by targeting Mpro and ACE2 using molecular docking. Eur. Rev. Med. Pharmacol. Sci. 2020, 24, $4529-4536$.

10. Jin, Y.H.; Cai, L.; Cheng, Z.S.; Cheng, H.; Deng, T.; Fan, Y.P.; Fang, C.; Huang, D.; Huang, L.Q.; Huang, Q.; et al. A rapid advice guideline for the diagnosis and treatment of 2019 novel coronavirus (2019-nCoV) infected pneumonia (standard version). Mil. Med. Res. 2020, 7, 4. [CrossRef]

11. Yang, Y.; Islam, M.S.; Wang, J.; Li, Y.; Chen, X. Traditional Chinese medicine in the treatment of patients infected with 2019-new coronavirus (SARS-CoV-2): A review and perspective. Int. J. Biol. Sci. 2020, 16, 1708-1717. [CrossRef]

12. Scalbert, A.; Johnson, I.T.; Saltmarsh, M. Polyphenols: Antioxidants and beyond. Am. J. Clin. Nutr. 2005, 81, 215s-217s. [CrossRef]

13. D'Archivio, M.; Filesi, C.; Di Benedetto, R.; Gargiulo, R.; Giovannini, C.; Masella, R. Polyphenols, dietary sources and bioavailability. Ann. Ist. Super. Sanita 2007, 43, 348-361. [PubMed]

14. Chauhan, B.; Kumar, G.; Kalam, N.; Ansari, S.H. Current concepts and prospects of herbal nutraceutical: A review. J. Adv. Pharm. Technol. Res. 2013, 4, 4-8. [PubMed]

15. Lee, I.C.; Ryu, C.W.; Bae, J.S. Novel herbal medicine C-KOK suppresses the inflammatory gene iNOS via the inhibition of p-STAT-1 and NF-kappa B. Biotechnol. Bioprocess Eng. 2020, 25, 536-542. [CrossRef]

16. Du, H.Z.; Hou, X.Y.; Miao, Y.H.; Huang, B.S.; Liu, D.H. Traditional Chinese Medicine: An effective treatment for 2019 novel coronavirus pneumonia (NCP). Chin. J. Nat. Med. 2020, 18, 206-210. [CrossRef]

17. Kim, J.S.; Kang, O.J.; Gweon, O.C. Comparison of phenolic acids and flavonoids in black garlic at different thermal processing steps. J. Funct. Foods 2013, 5, 80-86. [CrossRef]

18. Lim, H.J.; Nguyen, T.T.H.; Kim, N.M.; Park, J.S.; Jang, T.S.; Kim, D. Inhibitory effect of flavonoids against NS2B-NS3 protease of ZIKA virus and their structure activity relationship. Biotechnol. Lett. 2017, 39, 415-421. [CrossRef]

19. Nguyen, T.T.H.; Kang, H.K.; Kim, Y.M.; Jang, T.S.; Kim, D. Inhibition effect of flavonoid compounds against neuraminidase expressed in Pichia pastoris. Biotechnol. Bioprocess Eng. 2014, 19, 70-75. [CrossRef] [PubMed]

20. Nguyen, T.T.; Woo, H.J.; Kang, H.K.; Nguyen, V.D.; Kim, Y.M.; Kim, D.W.; Ahn, S.A.; Xia, Y.; Kim, D. Flavonoid-mediated inhibition of SARS coronavirus 3C-like protease expressed in Pichia pastoris. Biotechnol. Lett. 2012, 34, 831-838. [CrossRef]

21. Zhang, L.; Li, Y.Y.; Gu, Z.W.; Wang, Y.Y.; Shi, M.; Ji, Y.; Sun, J.; Xu, X.P.; Zhang, L.R.; Jiang, J.T.; et al. Resveratrol inhibits enterovirus 71 replication and pro-inflammatory cytokine secretion in rhabdosarcoma cells through blocking IKKs/NF-kappa B signaling pathway. PLoS ONE 2015, 10, e0116879.

22. Gahlawat, A.; Kumar, N.; Kumar, R.; Sandhu, H.; Singh, I.P.; Singh, S.; Sjostedt, A.; Garg, P. Structure-based virtual screening to discover potential lead molecules for the SARS-CoV-2 main protease. J. Chem. Inf. Model 2020, 60, 5781-5793. [CrossRef] 
23. Jang, M.; Park, Y.I.; Cha, Y.E.; Park, R.; Namkoong, S.; Lee, J.I.; Park, J. Tea polyphenols EGCG and theaflavin inhibit the activity of SARS-CoV-2 3CL-protease in vitro. Evid. Based Complement. Alternat. Med. 2020, 2020, 5630838. [CrossRef] [PubMed]

24. Balakin, K.V.; Savchuk, N.P.; Tetko, I.V. In silico approaches to prediction of aqueous and DMSO solubility of drug-like compounds: Trends, problems and solutions. Curr. Med. Chem. 2006, 13, 223-241. [CrossRef] [PubMed]

25. Nguyen, T.T.; Moon, Y.H.; Ryu, Y.B.; Kim, Y.M.; Nam, S.H.; Kim, M.S.; Kimura, A.; Kim, D. The influence of flavonoid compounds on the in vitro inhibition study of a human fibroblast collagenase catalytic domain expressed in E. coli. Enzyme Microb. Technol. 2013, 52, 26-31. [CrossRef]

26. Liu, A.L.; Wang, H.D.; Lee, S.M.Y.; Wang, Y.T.; Du, G.H. Structure-activity relationship of flavonoids as influenza virus neuraminidase inhibitors and their in vitro anti-viral activities. Bioorg. Med. Chem. 2008, 16, 7141-7147. [CrossRef]

27. Moga, M.A.; Dimienescu, O.G.; Arvatescu, C.A.; Mironescu, A.; Dracea, L.; Ples, L. The role of natural polyphenols in the prevention and treatment of cervical cancer-an overview. Molecules 2016, 21, 1055. [CrossRef]

28. Wang, S.C.; Chen, Y.; Wang, Y.C.; Wang, W.J.; Yang, C.S.; Tsai, C.L.; Hou, M.H.; Chen, H.F.; Shen, Y.C.; Hung, M.C. Tannic acid suppresses SARS-CoV-2 as adual inhibitor of the viral main protease and the cellular TMPRSS2 protease. Am. J. Cancer Res. 2020, 10, 4538-4546.

29. Stukelj, M.; Valencak, Z.; Krsnik, M.; Svete, A.N. The effect of the combination of acids and tannin in diet on the performance and selected biochemical, haematological and antioxidant enzyme parameters in grower pigs. Acta. Vet. Scand. 2010, 52, 19. [CrossRef]

30. Chung, K.T.; Wong, T.Y.; Wei, C.I.; Huang, Y.W.; Lin, Y. Tannins and human health: A review. Crit. Rev. Food Sci. 1998, 38, 421-464. [CrossRef] [PubMed]

31. Al-Hijazeen, M.; Lee, E.J.; Mendonca, A.; Ahn, D.U. Effects of Tannic acid on lipid and protein oxidation, color, and volatiles of raw and cooked chicken breast meat during storage. Antioxidants 2016, 5, 19. [CrossRef] [PubMed]

32. Zhang, L.; Lin, D.; Sun, X.; Curth, U.; Drosten, C.; Sauerhering, L.; Becker, S.; Rox, K.; Hilgenfeld, R. Crystal structure of SARS-CoV-2 main protease provides a basis for design of improved alpha-ketoamide inhibitors. Science 2020, 368, $409-412$. [CrossRef] [PubMed]

33. Fan, K.; Wei, P.; Feng, Q.; Chen, S.; Huang, C.; Ma, L.; Lai, B.; Pei, J.F.; Liu, Y.; Chen, J.; et al. Biosynthesis, purification, and substrate specificity of severe acute respiratory syndrome coronavirus 3C-like proteinase. J. Biol. Chem. 2004, 279, 1637-1642. [CrossRef] [PubMed]

34. Grum-Tokars, V.; Ratia, K.; Begaye, A.; Baker, S.C.; Mesecar, A.D. Evaluating the 3C-like protease activity of SARS-Coronavirus: Recommendations for standardized assays for drug discovery. Virus Res. 2008, 133, 63-73. [CrossRef] [PubMed]

35. Kuo, C.J.; Chi, Y.H.; Hsu, J.T.A.; Liang, P.H. Characterization of SARS main protease and inhibitor assay using afluorogenic substrate. Biochem. Biophys. Res. Commun. 2004, 31, 862-867. [CrossRef]

36. Rechtman, M.M.; Har-Noy, O.; Bar-Yishay, I.; Fishman, S.; Adamovich, Y.; Shaul, Y.; Halpern, Z.; Shlomai, A. Curcumin inhibits hepatitis Bvirus via down-regulation of the metabolic coactivator PGC-1 alpha. FEBS Lett. 2010, 584, 2485-2490. [CrossRef]

37. Tresserra-Rimbau, A.; Arranz, S.; Vallverdu-Queralt, A. New insights into the benefits of polyphenols in chronic diseases. Oxid. Med. Cell Longev. 2017, 2017, 1432071. [CrossRef]

38. Del Bo, C.; Bernardi, S.; Marino, M.; Porrini, M.; Tucci, M.; Guglielmetti, S.; Cherubini, A.; Carrieri, B.; Kirkup, B.; Kroon, P.; et al. systematic review on polyphenol intake and health outcomes: Is there sufficient evidence to define a health-promoting polyphenol-rich dietary pattern? Nutrients 2019, 11, 1355.

39. Grosso, G.; Stepaniak, U.; Topor-Madry, R.; Szafraniec, K.; Pajak, A. Estimated dietary intake and major food sources of polyphenols in the Polish arm of the HAPIEE study. Nutrition 2014, 30, 1398-1403. [CrossRef]

40. Li, R.F.; Hou, Y.L.; Huang, J.C.; Pan, W.Q.; Ma, Q.H.; Shi, Y.X.; Li, C.F.; Zhao, J.; Jia, Z.H.; Jiang, H.M.; et al. Lianhuaqingwen exerts anti-viral and anti-inflammatory activity against novel coronavirus (SARS-CoV-2). Pharmacol. Res. 2020, $156,104761$.

41. Luo, H.; Tang, Q.L.; Shang, Y.X.; Liang, S.B.; Yang, M.; Robinson, N.; Liu, J.P. Can Chinese medicine be used for prevention of corona virus disease 2019 (COVID-19)? a review of historical classics, research evidence and current prevention programs. Chin. J. Integr. Med. 2020, 26, 243-250. [CrossRef] [PubMed]

42. Ding, Y.W.; Zeng, L.J.; Li, R.F.; Chen, Q.Y.; Zhou, B.X.; Chen, Q.L.; Cheng, P.L.; Wang, Y.T.; Zheng, J.P.; Yang, Z.F.; et al. The Chinese prescription lianhuaqingwen capsule exerts anti-influenza activity through the inhibition of viral propagation and impacts immune function. BMC Complement. Altern. Med. 2017, 17, 130. [CrossRef]

43. Ryu, J.H.; Kang, D. Physicochemical Properties, biological activity, health benefits, and general limitations of aged black garlic: A review. Molecules 2017, 22, 919. [CrossRef]

44. Qiu, Z.C.; Zheng, Z.J.; Zhang, B.; Sun-Waterhouse, D.; Qiao, X.G. Formation, nutritional value, and enhancement of characteristic components in black garlic: A review for maximizing the goodness to humans. Compr. Rev. Food Sci. Food Saf. 2020, 19, 801-834. [CrossRef] [PubMed]

45. Coelho, C.; Gallo, G.; Campos, C.B.; Hardy, L.; Wurtele, M. Biochemical screening for SARS-CoV-2 main protease inhibitors. PLoS ONE 2020, 15, e0240079. [CrossRef] [PubMed]

46. Kandeel, M.; Al-Nazawi, M. Virtual screening and repurposing of FDA approved drugs against COVID-19 main protease. Life Sci. 2020, 251, 117627. [CrossRef] 
47. Rameshkumar, M.R.; Indu, P.; Arunagirinathan, N.; Venkatadri, B.; El-Serehy, H.A.; Ahmad, A. Computational selection of flavonoid compounds as inhibitors against SARS-CoV-2 main protease, RNA-dependent RNA polymerase and spike proteins: A molecular docking study. Saudi J. Biol. Sci. 2021, 28, 448-458. [CrossRef] [PubMed]

48. Cherrak, S.A.; Merzouk, H.; Mokhtari-Soulimane, N. Potential bioactive glycosylated flavonoids as SARS-CoV-2 main protease inhibitors: A molecular docking and simulation studies. PLOS ONE 2020, 15, e0240653.

49. Abd El-Mordy, F.M.; El-Hamouly, M.M.; Ibrahim, M.T.; Abd El-Rheem, G.; Aly, O.M.; Abd El-kader, A.M.; Youssif, K.A.; Abdelmohsen, U.R. Inhibition of SARS-CoV-2 main protease by phenolic compounds from Manilkara hexandra (Roxb.) Dubard assisted by metabolite profiling and in silico virtual screening. RSC Adv. 2020, 10, 32148-32155. [CrossRef]

50. Gogoi, N.; Chowdhury, P.; Goswami, A.K.; Das, A.; Chetia, D.; Gogoi, B. Computational guided identification of a citrus flavonoid as potential inhibitor of SARS-CoV-2 main protease. Mol. Divers. 2020, 1-5. [CrossRef]

51. Tu, Y.F.; Chien, C.S.; Yarmishyn, A.A.; Lin, Y.Y.; Luo, Y.H.; Lin, Y.T.; Lai, W.Y.; Yang, D.M.; Chou, S.J.; Yang, Y.P.; et al. A review of SARS-CoV-2 and the ongoing clinical trials. Int. J. Mol. Sci. 2020, 21, 2657. [CrossRef] [PubMed]

52. Hosseinzade, A.; Sadeghi, O.; Naghdipour Biregani, A.; Soukhtehzari, S.; Brandt, G.S.; Esmaillzadeh, A. Immunomodulatory effects of flavonoids: Possible induction of T CD4+ regulatory cells through suppression of mTOR pathway signaling activity. Front. Immunol. 2019, 10, 51. [CrossRef] [PubMed]

53. Regmi, S.; Choi, Y.S.; Kim, Y.K.; Khan, M.M.; Lee, S.H.; Cho, S.S.; Jin, Y.Y.; Lee, D.Y.; Yoo, J.C.; Suh, J.W. Endoglucanase produced by Bacillus subtilis Strain CBS31: Biochemical characterization, thermodynamic study, enzymatic hydrolysis, and bio-industrial applications. Biotechnol. Bioprocess Eng. 2020, 25, 104-116. [CrossRef] 